\begin{tabular}{|c|c|c|}
\hline $\begin{array}{l}\text { KULTURA } \\
\text { I } \\
\text { SPOLECZENS }\end{array}$ & $\begin{array}{l}\text { POLSKA AKADEMIA NAUK } \\
\text { KOMITET SOCJOLOGII } \\
\text { INSTYTUT STUDIÓW POLITYCZNYCH } \\
2015, \mathrm{nr} 4\end{array}$ & ISSN 0023-5172 \\
\hline
\end{tabular}

ALEKSANDER MANTERYS

Instytut Studiów Politycznych PAN

\title{
DARWIN ET CONSORTES: MIT DARWINA W KULTURZE WSPÓŁCZESNEJ
}

Postać Charlesa Darwina, a dokładniej: szeroka paleta koncepcji, poglądów i opinii towarzyszących recepcji jego dorobku, wciąż fascynuje kolejne pokolenia badaczy. Spór między kreacjonistami a ewolucjonistami daleki jest od rozstrzygnięcia, nawet wtedy gdy sięga się do rozwiązań w postaci odgórnie narzucanej wykładni określającej, co ma trafić pod postacią prawdy do umysłów uczniów i studentów (a także szerszej publiczności). Interesujące jest odnajdywanie refleksów tego sporu w pracach reprezentantów nauk społecznych i humanistycznych. W istocie jest to główny składnik szerszego uogólnionego dyskursu wokół natury i zakresu sprawczości ludzkiej, zarówno indywidualnej, jak i zbiorowej czy gatunkowej. Akcentuję ten punkt widzenia, albowiem czym innym jest rozstrzyganie, kto w tym sporze ma lepszą „amunicję”, a czym innym śledzenie, czy i w jakim stopniu pomysły Darwina są obecne w charakterystykach jednostek ludzkich ujmowanych jako istoty społeczne i kulturowe, czyli — by pozostać przy militarnych asocjacjach — czy i jakie składniki zaczerpnięte z Darwinowskiego arsenału znajdują zastosowanie w próbach zrozumienia fenomenu społeczeństw ludzkich.

Sytuacja jest zgoła paradoksalna. Mało kto kwestionuje inspirującą, wręcz przełomową rolę Darwina w kształtowaniu poglądów na naturę ludzką ${ }^{1}$. Ewolucja i dobór naturalny, jako składniki tego swoistego wyznania wiary, a przynajmniej idee naczelne organizujące naukową refleksję, jednoczą badaczy różnych orientacji i specjalności. Jedność ta jednak przechodzi nieuchronnie w wielość

Adres do korespondencji: amanterys@isppan.waw.pl

${ }^{1}$ Dokumentacja życia i dorobku: Darwin Online. 
i różnorodność pomysłów teoretycznych i zabiegów badawczych. Być może jest to przykład swoistej autopojetyczności „systemu teorii ewolucji”, a może i symbol pychy intelektu ludzkiego, ponawiana ustawicznie próba wznoszenia postewolucjonistycznej wieży Babel, przynosząca nie uniwersalistyczną jedność, lecz rozproszenie pod postacią rozlicznych glos niewspółmiernych narracji.

Nawet w ograniczonym obszarze nauk społecznych i humanistyki trudno orzekać o jakimś konsensie. Intelektualny ferment pod szyldem ewolucji rozpoczyna się jeszcze w czasach Darwina, głównie za sprawą Spencera (1888, 1898) i jego pomysłu na przetrwanie jednostek najlepiej przystosowanych. Pomysł ten, rozpracowywany przez Spencera na wielu płaszczyznach (począwszy od biologii, a skończywszy na moralności), staje się składnikiem szerszej koncepcji, która tłumaczy trwanie i zmianę społeczną, rozwój czy ewolucję organizmów ludzkich również w otoczeniu społecznym, które samo ulega ewolucyjnym przekształceniom pod szyldem lepszej adaptacji oraz rosnącej złożoności strukturalnej i funkcjonalnej. W gruncie rzeczy logika teoretyczna Spencera, mimo ułomności i zapożyczeń, jest protoformą resp. matrycą wszelkich kolejnych, mówiąc językiem Ingardena, konkretyzacji koncepcji ewolucji w naukach społecznych i humanistycznych, czy to w formie jawnych, czy skrytych nawiązań nie tyle do rozwlekłej prozy autora Social Statics, ile do sposobu patrzenia na mechanikę relacji społecznych. Uznana zostaje autonomia całego sektora ponadorganicznych relacji łączących jednostki, grupy jednostek i instytucje oraz ich otoczenia czy środowiska. Wykształcenie się czy (jak mówią niektórzy) emergencja tego sektora, choć w ostatecznym rachunku ma niejako biologiczny rodowód, w coraz większym stopniu jest kształtowana przez siły czy mechanizmy, które właściwe są jedynie społeczeństwom ludzkim. Mówiąc dzisiejszym językiem, dynamikę społeczeństw ludzkich można rozpisać na szerszym planie uwarunkowań tkwiących w genach i memach. Dalej: ewolucja to rosnące zróżnicowanie i zwiększona zdolność adaptacyjna, ale nie oznacza to prostej linearności (znanej z prac dewelopmentalistów), lecz nieokreśloną wielość dróg rozwojowych, zwiększoną różnorodność czy wielość form zróżnicowania i zawsze obecną możliwość regresji (dewolucji resp. rozpadu, przywołując terminologię Spencera). Charakterystyka mechanizmów adaptacyjnych to zarazem wskazanie kolejnych sektorów, podsystemów czy wymiarów egzystencji ludzkiej oraz sposobów „radzenia sobie” z otoczeniem, umiejętności uzyskiwania przez podmioty indywidualne i zbiorowe dostępu do cennych zasobów z jednoczesnym moralnym „nasyceniem” praktyk uznanych za legitymizowane. Jest to w pewnym sensie walka o przetrwanie, ale (by tak rzec) memetycznie resp. kulturowo skalibrowana.

Spencerowska receptura życia społecznego, a raczej konglomerat asocjacji wokół Darwina i koncepcji ewolucji znajduje rozliczne kontynuacje. Jest intelektualnie nośny i heurystycznie owocny. Parafrazując słynną wypowiedź Parsonsa (1968, s. 3 i nast.), Spencer jest martwy, ale przede wszystkim dlatego, iż jego pomysły zostały znacznie lepiej „zapakowane” przez Durkheima 
(1999), a później przez samego Parsonsa (1966, 1971), Lenskiego (1966; Lenski i in. 1995), Luhmanna (1982) i Sandersona (1995), a także odniesione wprost do ustaleń Darwina i jego kontynuatorów. Na przykład w wydaniu Luhmanna ewolucja to socjokulturowy proces różnicowania, który (by pominąć drobiazgowe wskazanie wszystkich wymiarów i konsekwencji) zwiększa kompleksowość systemu oraz elastyczność jego relacji z otoczeniem. Redukowania owej kompleksowości nie można sprowadzić do mechanizmów biologicznych, wymiar symboliczny wymusza komunikację i stosowanie wyspecjalizowanych mediów wymiany w kadencjach wariacji, selekcji i stabilizacji poszczególnych składników uniwersum społecznego (zob. też Luhmann 2007).

Gdyby wyjść poza opłotki szeroko rozumianego funkcjonalizmu, można bez szczególnego ryzyka orzekać o pewnym uogólnionym dyskursie, którego zasadniczym atrybutem jest uznanie, iż człowiek staje się ludzki dopiero w społeczeństwie. To ono, wraz ze swymi instytucjami, w szczególności poprzez normy i wartości kulturowe, kształtuje ludzi onto- i filogenetycznie. Ten sposób myślenia jest obecny u Durkheima (1999) w jego koncepcji homo duplex, u Meada $(1934,1938)$, który w samoświadomości i możności podejmowania ról widzi swoistość rodzaju ludzkiego, czy u Marksa (Marks, Engels 1976), który z wytwarzania specyficznie ludzkich form panowania nad otoczeniem czyni koło zamachowe prorozwojowej zmiany społecznej. Logika tego rozumowania jest silna i dziś: wystarczy wspomnieć koncepcje systemu światowego ukazujące ewolucję gospodarki światowej (zob. np. Wallerstein 1974-1989) czy koncepcje ponowoczesności, w których imaginaria autonomii i wyzwolenia jawią się jako cywilizacyjne osiągnięcia (zob. np. Harvey 1989). Oznacza to, przy wszystkich różnicach ideologicznych, zgodę (często domniemaną) na pojmowanie ewolucji jako koewolucji zachodzącej na wszystkich piętrach życia społecznego, i w tym sensie równorzędność, a niekiedy prymat tego, co ponadorganiczne, w procesach adaptacji czy (jak kto woli) walki o cenne zasoby (zob. zwłaszcza Boyd, Richerson 1989; Durham 1991).

Kontrapunktem tego sposobu myślenia jest akcentowanie tego, co biologiczne, a dokładniej - uznanie, iż mimo wszelkich ponadorganicznych oddziaływań natura ludzka pozostaje stosunkowo niezmienna, a wszelkie subtelności organizacji ludzkiej to pochodna materiału zawartego w puli genowej, wytwory, które pod względem wypracowania przewyższają kły lub pazury, pozostając „bez reszty” produktami doboru naturalnego. I nie ma tu znaczenia, czy będzie to samolubny gen, pospolite instynkty czy emocje: to, co biologiczne, poprzez swą konfigurację czy kompozycję, jest wprzęgnięte $\mathrm{w}$ tryby doboru naturalnego, lepszego dopasowania czy dostosowania w walce o przetrwanie i dominację (zob. Dawkins 1996, 2003; van der Berghe 1973, 1975, 1981; Wilson 2000, 2011; zob. też Mościskier 2001). Ten sposób myślenia wręcz kanibalizuje nauki społeczne i humanistykę, sprowadza byty i relacje społeczne do roli nośników czy narzędzi doboru naturalnego. Rzecz nie w tym, co często się podnosi, że zwolenników tego sposobu myślenia nie znamionuje 
wybitna wiedza o społeczeństwach i kulturach, ale w trwaniu w przekonaniu, że natura ludzka jest historycznie niezmienna, a jej biologiczny rodowód hamuje kształtowanie innych sposobów przystosowania i pozyskiwania cennych zasobów. Jest to równie „odkrywcze” i heurystycznie jałowe jak tezy neoliberalnych dogmatyków czy komunistycznych ortodoksów. Prowadzi do swoistego klinczu, który zniechęca do poznania trwałych i zmiennych związków między naturą i kulturą.

Klincz ten może być jednak rozerwany, jeśli strumień ortodoksji zostanie skierowany na inne nurty, być może meandryczne, ale heurystycznie obiecujące. Można na przykład uznać, iż genotypy jednostek faktycznie je programują w sensie skłonności czy preferencji do pewnych typów nacechowanych kulturowo zachowań. Selekcja ta dokonuje się wszakże w procesie uczenia się, socjalizacji, akulturacji, co tworzy szczególną, programowaną biologicznie, lecz moderowaną społecznie i kulturowo konfigurację, która stanowi podstawę selekcji (zob. np. Alexander R. D. 1987; Runciman 2000). A jeśli rozciągnąć pojęcie ewolucji na kulturę, to można mówić o doborze kulturowym i względnej niezależności dwóch domen ewolucji: organicznej i ponadorganicznej, koewolucji (zazwyczaj w sensie dual inheritance), której poszczególne „rozdania” wymagają zbadania, choćby w sensie „siły rażenia”, w określonych okolicznościach historycznych i sytuacyjnych, poszczególnych składników genotypów i memotypów oraz relacji między nimi (zob. np. Lynch 1996; Richerson, Boyd 2005).

Najbardziej nośna i obiecująca odmiana tego sposobu myślenia jest domeną psychologii ewolucyjnej. Jest to ambitna próba ujęcia natury człowieka oraz zjawisk społecznych i kulturowych w kategoriach uniwersalistycznych, poprzez wskazanie ukształtowanych ewolucyjnie mechanizmów psychologicznych i ich roli w procesie adaptacji (zob. np. Wright 1994). Mechanizmy te, na ogół pracujące poza udziałem świadomości i nieodnoszące się do maksymalizacji korzyści i logiki deliberatywnych lub samolubnych wyborów, konstytuują, ogólnie rzecz ujmując, pewien zbiór skłonności (emocji, dążności i preferencji), swoistą protoplazmę przemieszczającą się przez historycznie i sytuacyjnie dostępne kanały uwarunkowań naturalnych, strukturalnych i instytucjonalnych. W tym sensie te czy inne preferencje ani nie są dane raz na zawsze, ani też istoty ludzkie nie są „programowane” od nowa: mózg oraz inne organy są już niejako gotowe do zmagań $z$ adaptacją, zwiększenia sprawności czy efektywności zachowań adaptacyjnych (zob. Poleszczuk 2004). Taka logika teoretyczna tłumaczy nie tylko sukcesy adaptacyjne, progres $\mathrm{w}$ zmaganiach $\mathrm{z}$ otoczeniem, ale też konserwatyzm czy kompulsywność praktyk, które w określonych okolicznościach historycznych i sytuacyjnych zatraciły walor sprawności. Tak czy inaczej wyuczone mechanizmy psychologiczne to zasadnicze sprężyny działania ludzkiego, które są „ściskane” i „rozprężane” w okolicznościach społecznych i kulturowych $\mathrm{w}$ procesie interakcji z otoczeniem, kształtując, by nawiązać do Goffmana (2000), bardziej lub mniej udane występy na scenie życia codziennego. I jest to zarazem frapujące intelektualnie ujęcie fenomenu ludzkiej sprawczości: prze- 
możne oddziaływanie mechanizmów psychologicznych nie sprowadza się ani do prostej automatyki replikującej wyuczone skłonności, ani też (co ważniejsze) do uznania ich za z natury czy biegunowo przeciwstawne siłom tkwiącym w otoczeniu społecznym. Owe mechanizmy to potencje, które aktualizują się w poszczególnych domenach aktywności istot ludzkich. Są bardziej zasadami organizacji składników otoczenia niż splotem determinacji, który „odzwierzęca” czy „cywilizuje” kultura. Przemoc domowa, malunki Nikifora czy Sonata Księżycowa to pochodne działania mechanizmów psychologicznych, potencji urzeczywistnionych w określonych okolicznościach, ale nie wskutek inercji behawioralnej, przymusu strukturalnego czy woli bogów, lecz dzięki aktywności sprawców. Myślenie to, choć u podstaw zakłada „substancję”, czy to tę prymarną (psychologiczna), czy to jej konglomerat w postaci wytworzonych w toku ewolucji instytucji społecznych, staje się nieuchronnie relacyjne, gdyż jedynie poprzez odnalezienie związków łączących „naturę” i „kulturę” mechanika zachowań ludzkich jawi się jako uwarunkowana czy zaprogramowana - podług różnych stopni swobody, między biegunami emocjonalności i wyrachowania, impulsu i deliberacji, egoizmu i altruizmu czy fobii/opresji i wyzwolenia.

Ten przegląd stanowisk, nawet jeśli uznać jego skrótowość, byłby jednak niepełny, gdyby nie zostały wskazane zasadnicze racje, które skłaniają wielu uznanych badaczy do odrzucenia nie tylko idei ewolucji, ale całego towarzyszącego jej sztafażu, czy to w postaci doboru naturalnego, czy to $\mathrm{w}$ formie memów. Jednym ze źródeł tego sprzeciwu jest niechęć, a raczej pewnego rodzaju intelektualna asceza, która nakazuje nieufność wobec budowy uniwersalistycznych schematów teoretycznych. Nieufność taka, nawet jeśli trzymać się standardów oświeceniowej naukowości, jest uzasadniona, albowiem osobliwości świata kultury wymagają przestrzegania takich samych empirycznych rygorów, które pozwolą precyzyjnie rejestrować zdarzenia społeczne dokonujące się w określonych niszach czy sektorach kultur i społeczeństw, w różnym miejscu i czasie. Teoretyczna synteza jest wskazana, ale na gruncie znajomości konkretnych kultur i społeczeństw, kształtowanych w toku historii. Ta, znana za sprawą Boasa (1982), strategia badawcza w warstwie „ideologicznej” staje się antynaturalistyczną (w swych konsekwencjach antyewolucjonistyczna) tezą, która prowadzi do stawiania pytań o to, jak kształtowały się konkretne kultury i społeczeństwa. Stąd już tylko krok do uznania, iż wzory, style, konfiguracje, profile czy formy kultury tworzą autonomiczny obszar uwarunkowań i determinacji, który kształtuje sferę doświadczeniową jednostek.

W bardziej socjologicznym (i jawnie antyewolucjonistycznym) wydaniu Weberowski postulat poznawania zjawisk społecznych w ich historycznej specyficzności oznacza próbę wydobycia sensu zdarzeń dokonujących w sferze chaosu i antagonizmów, sensów, norm czy wartości, które są kształtowane $\mathrm{w}$ poczynaniach podmiotów działających. Zmiana społeczna to nie konkretyzacja mechanizmów ewolucji, lecz zapis poszczególnych splotów determinacji, niepowtarzalnych konfiguracji, które niekiedy przetworzone zostają $\mathrm{w}$ stosun- 
kowo trwałe wzory organizacji społecznej, raz zgodne $z$ instrumentalną racjonalnością, niekiedy zastygłe $\mathrm{w}$ tradycjonalnej inercji, a czasem powoływane do istnienia charyzmą przywódców.

Tę listę (niekiedy jeremiadę) możliwych sensownych odniesień do Darwina i koncepcji ewolucji można by ciągnąć ad libitum. Ukazałem jedynie te, które stanowią, $z$ mego punktu widzenia, najistotniejsze punkty odniesienia. Jest to skrócony, choć reprezentatywny dla mnie zapis "formacyjnych" teoretycznie argumentów i kontrargumentów, swoistych „za”, „przeciw” i „być może”. Układają się one, bez względu na moje osobiste idiosynkrazje, w sieci intelektualnych i pozaintelektualnych uwikłań w sporze wokół - by przywołać tytuł głośnej rozprawy Ossowskiego (1966) - więzi społecznej i dziedzictwa krwi. I jeśli nie trwać przy pojmowaniu teorii na wzór wyśnionych przez filozofów nauki idealnych jej wizerunków, podzielanych na jawie przez kolejne pokolenia socjologów, antropologów, ekonomistów itd., teorie można ujmować jako opowieści o tym, co i dlaczego się zdarza. W rozpatrywanym tu kontekście są to opowieści o tym, czy i w jakim stopniu, w jakich okolicznościach adaptacyjne relacje istot ludzkich $z$ otoczeniem przypominają czynności „programowanych" genetycznie zwierząt czy emanacje wolnych ego, a niekiedy, co stanowi specyficzny chichot procesu krążenia idei, zamieniają się w opisy jednostek, grup i zbiorowości w kategoriach genetycznego i memetycznego uprzyczynowienia, zaprogramowania czy wdrukowania. Taki sposób myślenia o teorii skłania do „poszerzenia pola walki”, by w imię własnej adaptacji do podjętego zadania wyzyskać tu tytuł słynnej książki Houellebecqa. Owo poszerzenie jest nieodzowne: skoro teorie są opowieściami, mają swoich twórców i odtwórców, protagonistów i antagonistów, chórki i widownie, których pola działania nie zamykają się w wąskim kręgu salonów i laboratoriów naukowych. I śledzenie tych przepływów idei, ich poszczególnych konkretyzacji w różnych, mówiąc językiem Bourdieu (2005) czy Martina (2009), polach działania jest nadzwyczaj intelektualnie intrygujące i wskazane. Ukazuje rzeczywisty świat rywalizacji o panowanie w sferze idei oraz częstokroć reorganizację społeczeństwa i kultury podług dominujących standardów. Jak określiliby to Fligstein i McAdam (2011), ma się do czynienia z kształtowaniem się różnych porządków lokalnych, zmiennych historycznie, instytucjonalnie i sytuacyjnie. Lub też, by nawiązać do Collinsa (1998), śledząc zmianę intelektualną, można rekonstruować nie tylko intelektualne alianse i konflikty, ale też śledzić społeczne tło procesu krążenia idei.

Książka Dominiki Oramus, Darwinowskie paradygmaty: mit teorii ewolucji $w$ kulturze wspótczesnej (2015)², której lektura zmotywowała mnie do napisania tego eseju, już w tytule ustawia cały koncept ewolucji (i postać samego Darwina) w sposób co najmniej frapujący. Po pierwsze, zobowiązujące określe-

\footnotetext{
2 Dalej powołując się na tę książkę podaję w tekście numer strony.
} 
nie „paradygmaty” działa jak zaczyn intelektualnej indukcji, procesu, którego tworzywo stanowią rozliczne próby skodyfikowania dróg rozwojowych nauki. Nawet jeśli obstawać przy Luhmannowskiej wykładni, która nakazuje myślenie w kategoriach prawdy jako uogólnionego medium wymiany w sektorze produkcji naukowej, oryginalne zamącenie gatunku, którego sprawcą pozostaje Kuhn (2009), skłania do pytania, czy oddziaływanie koncepcji Darwina faktycznie oznacza rewolucję naukową oraz jakie są jej konsekwencje, nie tylko te stricte naukowe (czy to w sensie monoparadygmatycznej science, czy to w nieco mniej zobowiązującej postaci wielości paradygmatów), ale też odniesione do domeny życia codziennego i sfery kultury. I po drugie, co stanowi differentia specifica analiz Oramus, istotne staje się śledzenie opowieści, narracji, dyskursów, praktyk, form czy stylów obecności konceptu ewolucji w tym, co (po Marksowsku ujmując) składa się na nadbudowę, która zwrotnie oddziałuje na praktyki aktorów indywidualnych i zbiorowych, stanowi (powiedziałby Bourdieu) istotny składnik instrumentarium przemocy symbolicznej, kształtujący praxis i dostępne interakcyjnie habitusy, czy wreszcie (jak by określił to Fligstein w duchu zmodyfikowanego neoinstytucjonalizmu) składa się na kompetencje społeczne ujawniane $\mathrm{w}$ ramach pól, lokalnych i ponadlokalnych porządków społecznych zasadniczych obszarów działania strategicznego aktorów. Te trzy przykładowe odniesienia, jak też wiele innych, zwłaszcza osadzonych $\mathrm{w}$ tradycji studiów kulturowych, przenoszą ciężar analizy na (rozumiany po Mannheimowsku) proces krążenia idei lub (wyrażając to zgodnie $z$ tym, co niektórzy uznają za haute couture analiz życia społecznego) ukrytą logikę scenariuszy performansów.

Oramus, co wprost wypowiada we „Wstępie”, chce ukazać „[...] funkcjonowanie mitu Karola Darwina w dzisiejszym świecie" (s. 7), dość egalitarnie traktując wszelkie okruchy kultury, w tym niekiedy co najwyżej średniej jakości filmy fabularne i powieści, jako składniki „tekstów” konstytuujących kulturowo-społeczne obiegi opatrzone szyldami Darwina, darwinizmu czy ewolucji. Zasadnicza trudność tkwi w określeniu zasady selekcji (co, być może, jest powodowane pewną złośliwością czy opornością samego tworzywa), aranżacji niewspółmiernych zgoła składników, wyekstrahowanych niejako z różnych kontekstów historycznych, naukowych, filozoficznych, instytucjonalnych i sytuacyjnych, w harmonijną opowieść o fenomenie darwinizmu we współczesnym świecie. Selekcja taka, z czym w zupełności zgadzam z Oramus, jest nieodzowna, choć zarazem arbitralna, po Weberowsku jednostronna. Trudność tego zabiegu jest spora, albowiem ma się do czynienia nie tylko z pospolitą (i dość oczywista) wielością kontekstów, ale też wielopoziomowością czy wielowymiarowością składników mitu Darwina, jak określa to autorka, oraz z koniecznością ujmowania go jako jednego z wielu mitów kosmogonicznych, rywalizujących na rynku idei o dusze swych pro- i antagonistów. Mogę nie podzielać wyborów autorki, ale w pełni (tak nieskromnie sądzę) rozumiem i podzielam potrzebę wręcz kartezjańskiej organizacji splątanego pandemonium okołodarwinowskich konkretyzacji. Oramus śledzi kulturową warstwę 
funkcjonowania mitu Darwina, odnajdując ważkie egzemplifikacje w tym, co mówiąc za bohaterami i antybohaterami narracji Kłoskowskiej (1980) mieści się $\mathrm{w}$ obszarze kultury wysokiej, jak też bytuje w kulturze jedynie $\mathrm{z}$ określeniem „popularna” czy „masowa”. Jedno i drugie wszakże jest istotne, gdyż bez względu na wynoszące resp. deprecjonujące określniki, mieści się w domenie kultury obiektywnej, tego demona, który (zgodnie z logiką rozumowania Simmla) jest wytworem ludzkich subiektywności, ale raz ustanowiony wyznacza możliwe trajektorie tego, co ważne czy cenne resp. błahe i bez znaczenia.

Organizacja tego powikłanego tworzywa okruchów kultury, w sensie kompozycji poszczególnych partii książki Oramus, jest nienaganna. „Wstęp”, co zawsze warto podkreślić, w zwartej formie ukazuje problem mitu Darwina, wokół którego koncentrują się kolejne kroki analizy autorki. Odsłona pierwsza to próba określenia natury darwinowskich paradygmatów. Nieco zjadliwe uwagi autorki o „Świętym Graalu nauk ścisłych”, czyli pojmowaniu koncepcji Darwina jako nadrzędnej metanarracji w kategoriach ideału, „wszechogarniającej teorii wszystkiego", ustawiają rzecz comme il faut. Odnoszą się do takich teorii, których siła rażenia wykracza poza obszar dyscypliny czy dziedziny naukowej, nie tylko rewolucjonizujących pojmowanie zjawisk w określonej domenie nauki, ale też oddziałujących przemożnie, jako metafory, przybliżenia czy innej maści przetworzenia, na wyobrażenia w potencjalnie każdej sferze aktywności człowieka, organizujących jego/jej światopogląd. Słowem, poszczególne oglądy darwinizmu, niczym $\mathrm{w}$ antropologicznych koncepcjach dyfuzji, przenikają stopniowo z obszaru nauk przyrodniczych, historii naturalnej do nauk niebiologicznych, w tym literaturoznawstwa. Są to, rzecz jasna, opowieści coraz bardziej przetworzone i zróżnicowane literacko, ale (by wyrazić to w nieco kapsularnej postaci) podtrzymujące wiarę w ewolucję, zdeterminowanie genetyczne oraz możliwość ujęcia zjawisk społecznych i kulturowych w kategoriach doboru naturalnego i postępu. Rzecz nie w tym, czy opowieści te są prawdziwe, czy też nie, lecz w tym, co celnie konstatuje Oramus, że: „Metaforycznie rozumiany dobór naturalny stał się określeniem procesów kształtujących rozmaite byty - niekoniecznie organiczne. Rywalizują, dostosowują się do środowiska i reprodukują się, przynajmniej na kartach wydawanych współcześnie książek, myśli, memy, jednostki leksykalne, a nawet wszechświaty" (s. 33).

Osłona druga to prezentacja Darwina jako bohatera mitycznego. Dokładniej rzecz ujmując, podejście Oramus, choć zakotwiczone pierwotnie w historii nauki, wykracza poza zużyte heurystyczne ramy historii nauki i historii idei. Jest opowieścią o powstawaniu i przemianie mitu Darwina, a raczej całego pakietu konstrukcji mitycznych, które dotyczą jego postaci, poglądów, darwinizmu, ewolucji, historii naturalnej, a później genów i memów. Jest to narracja polifoniczna, ale też polichromiczna w sensie kolejnych nawarstwień, czy to w duchu „heroizacji”, czy też „odbrązowienia”, niekiedy „satanizacji”, oraz poliarchiczna w sensie politycznych, kulturowych i sytuacyjnych supremacyjnych przepychanek wokół kompleksu Darwina et consortes. Oramus, w kilku krokach 
analitycznych, zarówno bardzo zręcznie odsłania swoistość postaci, myślenia i działania Darwina, jak też ukazuje osadzenie tychże swoistych elementów i procesów w koleinach ducha epoki. Darwin pod pewnymi względami był do bólu typowy: poszukujący praw elementarnych, ulegający modom intelektualnym, powiewom maltuzjanizmu i powabom narracji osiemnastowiecznych podróżników, gawędziarski w stylu pisarskim — by wspomnieć tylko najistotniejsze składniki tego kulturowego „nacechowania”. I właśnie ten „kulturowy wiktorianin", dziewiętnastowieczny dżentelmen staje się herosem, odkrywcą i piewcą prawdy, a jego teoretyczna opowieść przechodzi w mit o początkach świata i powstaniu ludzkości: „Darwin to każdy z nas, pojął coś ważnego, lecz kontrowersyjnego; boi się to ogłosić, wiedząc jednocześnie, że to jego obowiązek" (s. 41). Nie jest to jedynie opowieść o bohaterze, lecz epopeja, której postaci i zdarzenia konstytuują wręcz nową religię. Bohater staje prorokiem, część jego wyznawców - apostołami, a poszczególne zdarzenia i uczynki, czy to dżentelmeńskie uznanie wkładu innych odkrywców i badaczy, czy to skatalogowanie różnych gatunków zięb, czy to wiara, iż gruntowna wiedza o procesach zachodzących obecnie wystarczy do zrozumienia genezy zjawisk, stają się składnikami nowego sacrum. Ten nowy Kościół zastępuje w końcu osobowego Boga bezosobowym zegarmistrzem, „[...] który działając bez planu, stworzył złożoność i piękno" (s. 20).

Rozmaite odmiany i pochodne funkcjonowania praw natury dopełniaja, w rękach biografów, komentatorów i różnej maści prozelitów, mit założycielski tej nowej religii. Stąd już tylko krok do przejścia od faktów i dokładności historycznej do fantazji, od relacji do anegdot i przypowieści, czyli fikcji wzmacniających antybiblijną opowieść o stworzeniu, która sama (tak jak szereg innych okołodarwinowskich opowieści) staje się składnikiem, wręcz „dopalaczem”, w konflikcie między nauką i religią. Oramus nie bez racji konstatuje stylistyczne pokrewieństwo tego mitu i współczesnych wykładni odnoszenia się do przeszłości: nieśmiertelną wręcz skłonność do tworzenia wielkich narracji, które przechodzą w „symulacje wielkiej historii” (s. 75). Ta gra wyobraźni, co świetnie dokumentuje autorka, nigdy się nie kończy, stanowiąc zaczyn kolejnych opowieści, w tym „apokryficznych”, których tematyka może dotyczyć nerwowej i zdrowotnej kondycji samego Darwina, poszukiwań utraconego Edenu czy też umiarkowanych zdolności i wtórności ustaleń naukowych, niebywałego szczęścia i wszechogarniającej kontyngencji, która tłumaczy genezę jego odkryć i „odkryć”. Ten wir nawarstwień, społeczno-kulturowej dyfuzji, niekończących się zastosowań i uproszczeń, niczym w słynnym opowiadaniu Poego, zagarnia wszelkie składniki społeczno-kulturowego pandemonium. Jest w pewnym sensie wiecznotrwały, ale też wszechpotężny i wszechobecny: począwszy od platformy konfliktu między nauką a religia, poprzez naukowe próby opisu świata naturalnego, intelektualne ekscesy socjobiologów, a skończywszy na science fiction, kreskówkach i pandemii parków jurajskich (by w ten, nieco zgryźliwy sposób, nawiązać do wyobrażeń „mas rządzących” o nowoczesno- 
ści i społeczeństwie obywatelskim). Nawiązując wprost do ustaleń Oramus audyt mitu o Darwinie, jego adaptacji i przeróbek, ukazuje wielość wydźwięków ideologicznych, jego współwłasność w sensie wszechobecności w kulturze oraz przemieszanie faktów i fikcji (s. 111). Trywializując, a raczej odnosząc się do „logiki” paroksyzmów massmedialnej papki kultury współczesnej — dobór naturalny może posłużyć zarówno jako ideologiczna amunicja w czystce etnicznej, jak też jako uzasadnienie dobrosąsiedzkich stosunków na zasadach partnerstwa lub dominacji i podległości, nie wspominając już o „najlepiej przystosowanych" w realiach światowej gospodarki rynkowej finansistach i bankierach. By przywołać fragment własnej wakacyjnej lektury: „Abrams przyjrzał jej się z bliska. Nosiła zwykłą, białą, jedwabną sukienkę. [...] Prawie nie miała makijażu. Zdrowie i bogactwo, pomyślał. Szczupła, schludna, ładna i przystojna i pewnie nawet inteligentna. Końcowy etap ewolucji gatunków" 3 .

Kolejne odsłony książki Oramus to intelektualne wypady ilustrujące tezy autorki w obszarach opowieści o historii naturalnej, relacji między socjobiologią i kulturą, nauką i rozrywką, obecności genetyki w powieściach dwudziestowiecznych, początkach rodzaju ludzkiego i związkach darwinowskich paradygmatów z kwestiami metafizycznymi. Każda z tych „wypraw” została solidnie udokumentowana, choć jest (zgodnie z zamierzeniami autorki) selekcją wątków i egzemplifikacji. Te poszczególne parady symulakrów, czyli fakto-fikcji stanowią tworzywo w zgrabnej rekonstrukcji mechanizmów tworzenia i trwania poszczególnych kulturowych wizerunków darwinizmu, niekiedy optymistycznych, kiedy indziej zaś złowieszczych. Rzecz jasna, można „dołożyć” własne wizerunki, produkty czytelniczej konsumpcji kulturowej, i w ten sposób szukać potwierdzenia lub zwątpienia wobec tez i analiz Oramus. Zapewne niektórzy znajdą nieścisłości lub pytać będą, dlaczego zabrakło klasycznej dziś prozy Asimova i Herberta, cudownych ramotek w stylu Zakazanej planety (1956, reż. Fred M. Wilcox) czy też współczesnej prozy Dukaja. Siłą książki Oramus jest pewnego rodzaju półotwartość: autorka zaprasza do intelektualnej podróży, której ramy są przez nią określone. Jeśli ktoś chce, może i powinien zastanowić się, czy jej analizy stosują się do innych spektakularnych przypadków, fakto-fikcji kultury masowej. Hic Rhodus, hic salta! Sam zapewne inaczej ustawiłbym rozważania wokół paradygmatów, wypychając z pierwszego planu Poppera i opowiadając się za wielowymiarowym myśleniem o nauce i teoriach (zob. np. Alexander J. C. 1982; Fuchs 1992, 2001). Inaczej potraktowałbym mit Darwina, traktując go jeszcze bardziej zdecydowanie jako religię (czy antyreligię, jak kto woli). Nie kruszyłbym kopii z Wilsonem, ale raczej zmierzył się z bardziej zobowiązującymi intelektualnie koncepcjami ewolucji w wydaniu Luhmanna lub Sandersona. I wreszcie, sięgnąłbym do nieco innych egzemplifikacji mitu czy quasi-religii Darwina. Są to dość oczywiste różnice w osobniczej ontogenezie,

${ }^{3}$ Nelson DeMille, Odyseja Talbota, tłum. Małgorzata Klimek, W.A.B., Warszawa 2014, s. 116. 
które nie rzutują na ocenę książki Oramus. Jest to wciągająca lektura, która stanowi istotny wkład w zrozumienie losów darwinizmu, stawia ważne kwestie, oferuje intrygujące analizy. Jednym $z$ wielu moich osobistych pożytków jest to, iż lepiej rozumiem, dlaczego teoria ewolucji w wydaniu Spencera musiała odejść w zapomnienie. Widzę zarazem potrzebę gruntownego zbadania najbardziej złowieszczego wątku czy „odprysku” darwinizmu społecznego, nie tego związanego ze Spencerem czy Gumplowiczem, lecz z Gobineau i Postawami XIX stulecia Chamberlaina, które stały się formacyjną lekturą dla Josepha Goebelsa. Szerzej: relacje między pomysłami niektórych wyznawców Darwina a wymuszoną odgórnie budową nowych społeczeństw, odzwierciedlone także w wytworach kultury i praktykach inżynierii społecznej, to także fakto-fikcyjne opowieści o historycznym, kulturowym i politycznym znaczeniu, i to nie tylko te, nad którymi unosi się duch faszyzmu i komunizmu, ale też powojenna eugenika w krajach skandynawskich. Kończąc własną opowieść, stwierdzę, iż moje własne rozterki to rany symboliczne, która otwarła lektura książki Oramus. I tym cechują się dobre książki, iż nie można obok nich przejść obojętnie.

\section{BIBLIOGRAFIA}

Alexander Jeffrey C., 1982, Theoretical Logic in Sociology, t. 1: Positivism, Presuppositions, and Current Controversies, University of California Press, Berkeley-Los Angeles CA.

Alexander Richard D., 1987, The Biology of Moral Systems, Adline de Gruyter, New York.

Boas Franz, 1982 [1940], Race, Language, and Culture, The University of Chicago Press, Chicago.

Bourdieu Pierre, 2005 [1979], Dystynkcja. Spoteczna krytyka władzy sądzenia, tłum. Piotr Biłos, Scholar, Warszawa.

Boyd Robert, Richerson Peter J., 1989, Culture and the Evolutionary Process, Chicago University Press, Chicago IL.

Collins Randall, 1998, The Sociology of Philosophies: A Global Theory of Intellectual Change, The Belknap Press of Harvard University Press, Cambridge MA-London.

Dawkins Richard, 1996 [1976/1989], Samolubny gen, tłum. Marek Skoneczny, Prószyński i S-ka, Warszawa.

Dawkins Richard, 2003 [1982], Fenotyp rozszerzony. Dalekosiężny gen, tłum. Joanna Gliwicz, Prószyński i S-ka, Warszawa.

Durham William H., 1991, Coevolution: Genes, Culture, and Human Diversity, Stanford University Press, Stanford CA.

Durkheim Émile, 1999 [1893], O podziale pracy społecznej, tłum. Krzysztof Wakar, Wydawnictwo Naukowe PWN, Warszawa.

Fligstein Neil, Doug McAdam, 2011, Toward a General Theory of Strategic Action Fields, „Sociological Theory", t. 29, nr 1, s. 1-26.

Fuchs Stephan, 1992, The Professional Quest for Truth: A Social Theory of Science and Knowledge, State University of New York Press, Albany NY.

Fuchs Stephan, 2001, Against Essentialism: A Theory of Culture and Society, Harvard University Press, Cambridge MA-London.

Goffman Erving, 2000 [1959], Człowiek $w$ teatrze życia codziennego, tłum. Helena Datner-Śpiewak, Paweł Śpiewak, Wydawnictwo KR, Warszawa. 
Harvey David, 1989, The Condition of Postmodernity: An Enquiry into the Origins of Cultural Change, Blackwell, Oxford.

Kłoskowska Antonina, 1980, Kultura masowa. Krytyka i obrona, Państwowe Wydawnictwo Naukowe, Warszawa, wyd. 2.

Kuhn Thomas, 2009 [1962], Struktura rewolucji naukowych, tłum. Helena Ostromęcka, Justyna Nowotniak, Aletheia, Warszawa.

Lensky Gerhard, 1966, Power and Privilege: A Theory of Social Stratification, McGraw-Hill, New York.

Lenski Gerhard, Nolan Patrick, Lenski Jean, 1995, Human Societies: An Introduction to Macrosociology, McGraw-Hill, New York, wyd. 7.

Luhmann Niklas, 1982, The Differentiation of Society, tłum. Stephen Holmes, Charles Larmore, Columbia University Press, New York.

Luhmann Niklas, 2007 [1984], Systemy społeczne. Zarys ogólnej teorii, tłum. Michał Kaczmarczyk, Nomos, Kraków.

Lynch Aaron, 1996. Thought Contagion: How Belief Spreads Through Society. The New Science of Memes, Basic Books, New York.

Marks Karol, Engels Fryderyk, 1976 [1848], Manifest komunistyczny, tłum. Witold Piekarski, Książka i Wiedza, Warszawa.

Martin John Levi, 2009 [2003], Co to jest teoria pola?, tłum. Agata Dziuban, w: Aleksander Manterys, Janusz Mucha (red.), Michał Kaczmarczyk (współpr.), Nowe perspektywy teorii socjologicznej. Wybór tekstów, Nomos, Kraków.

Mead George Herbert, 1934, Mind, Self, and Society from the Standpoint of a Social Behaviorist, Chicago University Press, Chicago.

Mead George Herbert, 1938, The Philosophy of Act, Chicago University Press, Chicago.

Mościskier Andrzej, 2001, Natura ludzka i problem przestępczości, Wydawnictwo Akademickie Żak, Warszawa.

Oramus Dominika, 2015, Darwinowskie paradygmaty. Mit teorii ewolucji w kulturze wspótczesnej, Copernicus Center Press, Kraków.

Ossowski Stanisław, 1966 [1948], Więź społeczna i dziedzictwo krwi, w: Stanisław Ossowski, Dzieła, t. 2, Państwowe Wydawnictwo Naukowe, Warszawa.

Parsons Talcott, 1968 [1937], The Structure of Social Action, The Free Press, New York.

Parsons Talcott, 1966, Societies: Evolutionary and Comparative Perspectives, The Free Press, New York.

Parsons Talcott, 1971, The System of Modern Societies, Prentice Hall, Englewood Cliffs NJ.

Poleszczuk Jan, 2004, Ewolucyjna teoria interakcji spotecznych, Scholar, Warszawa.

Richerson Peter J., Boyd Robert, 2005, Not by Genes Alone: How Culture Transformed Human Evolution, University of Chicago Press, Chicago.

Runciman W. G., 2000, The Social Animal, The University of Michigan Press, Ann Arbor.

Sanderson Stephen K., 1995, Social Transformations: A General History of Historical Development, Blackwell, Cambridge MA.

Spencer Herbert, 1888 [1852], Social Statics, D. Appleton, New York.

Spencer Herbert, 1898, The Principles of Sociology, D. Appleton, New York.

van der Berghe Pierre, 1973, Age and Sex in Human Societies: A Biosocial Perspective, Wadsworth, Belmont CA.

van der Berghe Pierre, 1975, Man and Society: A Biosocial View, Elsevier, New York.

van der Berghe Pierre, 1981, The Ethnic Phenomenon, Elsevier, New York.

Wallerstein Immanuel, 1974-1989, The Modern World-System, 3 t., Academic Press, New York.

Wilson Edward O., 2000 [1975], Socjobiologia, tłum. Mariusz Siemiński, Wydawnictwo Zysk i S-ka, Poznań.

Wilson Edward O., 2011 [1998], Konsiliencja. Jedność wiedzy, tłum. Jarosław Mikos, Zysk i S-ka, Poznań. 
Wright Robert, 1994, The Moral Animal: Why We Are, the Way We Are. The New Science of Evolutionary Psychology, Vintage Books, New York.

Darwin Online (http://darwin-online.org.uk).

\section{DARWIN ET CONSORTES: DARWINIAN MYTH IN CONTEMPORARY CULTURE}

\section{Summary}

Dominika Oramus's book Darwinowskie paradygmaty: mit teorii ewolucji $w$ kulturze wspótczesnej [Darwinian Paradigms: The Myth of the Theory of Evolution in Contemporary Culture] is an attempt to trace Darwin's theory of evolution in today's world. The presence of this idea is noted in numerous complexes of fact and fiction, which are transformations of the original theory of evolution. These are the stuff of cultural production, whose creations shape individual and collective representations in almost every area of human activity. Commentary on Oramus's findings is placed in the context of the disputes-ever present in the social sciences-over the reception of Darwin's theory.

\section{Key words/słowa kluczowe}

Dominika Oramus; Charles Darwin / Karol Darwin; Darwinism / darwinizm; evolution / ewolucja; contemporary culture / kultura współczesna 